DOI: $10.1515 / a d m s-2017-0042$

\author{
K. Rokosz ${ }^{1}$, T. Hryniewicz ${ }^{1}$, S. Raaen ${ }^{2}$, D. Matýsek ${ }^{3}$, L. Dudek $^{1}$, K. Pietrzak ${ }^{1}$ \\ ${ }^{1}$ Koszalin University of Technology, Faculty of Mechanical Engineering, Department of \\ Engineering and Informatics Systems, Division of Bioengineering and Surface Electrochemistry, \\ Koszalin, Poland \\ ${ }^{2}$ Department of Physics, Norwegian University of Science and Technology, Gløshaugen, Norway \\ ${ }^{3}$ Faculty of Mining and Geology, Technical University of Ostrava, Ostrava-Poruba, Czech Rep. \\ rokosz@tu.koszalin.pl
}

\title{
SEM, EDS, AND XPS CHARACTERIZATION OF COATINGS OBTAINED ON TITANIUM DURING AC PLASMA ELECTROLYTIC PROCESS ENRICHED IN MAGNESIUM
}

\begin{abstract}
Plasma Electrolytic Oxidation (PEO) known also as Micro Arc Oxidation (MAO) process is widely used to fabricate porous coatings on titanium and its alloys mainly in water- and acid-based solutions to different applications, e.g. in biomaterials, catalysts, and sensors. In the present paper, the SEM, EDS, and XPS results of porous coatings obtained by PEO treatment on titanium in electrolytes based on concentrated phosphoric $\mathrm{H}_{3} \mathrm{PO}_{4}$ acid with calcium nitrate tetrahydrate $\mathrm{Ca}\left(\mathrm{NO}_{3}\right)_{2} \cdot 4 \mathrm{H}_{2} \mathrm{O}$, or magnesium nitrate hexahydrate $\mathrm{Mg}\left(\mathrm{NO}_{3}\right)_{2} \cdot 6 \mathrm{H}_{2} \mathrm{O}$, or zinc nitrate hexahydrate $\mathrm{Zn}\left(\mathrm{NO}_{3}\right)_{2} \cdot 6 \mathrm{H}_{2} \mathrm{O}$ for 3 minutes at $200 \mathrm{Vpp}$ (peak to peak) with frequency of $50 \mathrm{~Hz}$, are presented. Based on EDS results, the $\mathrm{Ca} / \mathrm{P}, \mathrm{Mg} / \mathrm{P}$, and $\mathrm{Zn} / \mathrm{P}$ ratios, which equal to $0.95,0.176$, and 0.231 , respectively, were found out. The XPS studies of the top $10 \mathrm{~nm}$ of the porous layer clearly indicate that it contains mainly phosphates $\left(\mathrm{PO}_{4}{ }^{3-}\right.$ and/or $\mathrm{HPO}_{4}{ }^{2-}$ and/or $\mathrm{H}_{2} \mathrm{PO}_{4}{ }^{-}$, and/or $\left.\mathrm{P}_{2} \mathrm{O}_{7}{ }^{4-}\right)$ with titanium $\left(\mathrm{Ti}^{4+}\right)$ and calcium $\left(\mathrm{Ca}^{2+}\right)$ or magnesium $\left(\mathrm{Mg}^{2+}\right)$, or $\mathrm{zinc}\left(\mathrm{Zn}^{2+}\right)$.
\end{abstract}

Keywords: Plasma Electrolytic Oxidation (PEO), Micro Arc Oxidation (MAO), CP Titanium Grade 2, calcium nitrate tetrahydrate $\mathrm{Ca}\left(\mathrm{NO}_{3}\right)_{2} \cdot 4 \mathrm{H}_{2} \mathrm{O}$, magnesium nitrate hexahydrate $\mathrm{Mg}\left(\mathrm{NO}_{3}\right)_{2} \cdot 6 \mathrm{H}_{2} \mathrm{O}$, zinc nitrate hexahydrate $\mathrm{Zn}\left(\mathrm{NO}_{3}\right)_{2} \cdot 6 \mathrm{H}_{2} \mathrm{O}$

\section{INTRODUCTION}

Nano-passive layers may be obtained by electrochemical treatments, such as standard and high-current density electropolishing (EP) [1-2] as well as magnetoelectropolishing (MEP) [3-4], while the thicker (micrometer scale) and more biocompatible coatings may be obtained by Plasma Electrolytic Oxidation (Micro Arc Oxidation) processes, e.g. under DC [5], DC pulsed [6] and AC [7] regimes on titanium [8] and its alloys (Ti6Al4V [9-10], Ti-15Mo [11], NiTi [12], Ti-6Al-7Nb [13], Ti-Nb-Zr-Sn [14]). It should also be pointed out that the PEO coatings may be 
used inter alia in biomaterials [15], sensors [16], and aerospace applications [17]. In previous works, the analysis of porous PEO coatings obtained on titanium under DC regime in electrolytes based on concentrated phosphoric acid with nitrates of copper [18], calcium [19], magnesium [20], zinc [20], were described, that may be a solid basis for further research on ACPEO coatings, what is presented in this paper.

\section{EXPERIMANTAL}

Samples of CP Titanium Grade 2 with dimensions of $10 \mathrm{~mm} \times 10 \mathrm{~mm} \times 2 \mathrm{~mm}$ were used for treatment in plasma electrolytic oxidation (PEO) process. Voltage of $200 \mathrm{~V}_{\mathrm{pp}}$ with the use of 50 $\mathrm{Hz} \mathrm{AC}$ power transformer was employed for titanium treatment. Electrolytes were composed of $500 \mathrm{~g}$ calcium nitrate tetrahydrate $\mathrm{Ca}\left(\mathrm{NO}_{3}\right)_{2} \cdot 4 \mathrm{H}_{2} \mathrm{O}$ in $1 \mathrm{~L}$ of concentrated $85 \%$ phosphoric acid $\mathrm{H}_{3} \mathrm{PO}_{4}$ or $500 \mathrm{~g}$ magnesium nitrate hexahydrate $\mathrm{Mg}\left(\mathrm{NO}_{3}\right)_{2} \cdot 6 \mathrm{H}_{2} \mathrm{O}$ in $1 \mathrm{~L}$ of concentrated $85 \%$ phosphoric acid $\mathrm{H}_{3} \mathrm{PO}_{4}$ or $500 \mathrm{~g}$ zinc nitrate hexahydrate $\mathrm{Zn}\left(\mathrm{NO}_{3}\right)_{2} \cdot 6 \mathrm{H}_{2} \mathrm{O}$ in $1 \mathrm{~L}$ of concentrated $85 \%$ phosphoric acid $\mathrm{H}_{3} \mathrm{PO}_{4}$. The process was performed in a glass vessel with $500 \mathrm{~mL}$ of electrolyte for 3 minutes. The Scanning Electron Microscope (SEM) FEI Quanta 650 FEG equipped with Energy-Dispersive X-ray Spectroscopy (EDS) for surface analysis was employed. The microscope operated under the following conditions: voltage $15 \mathrm{kV}$, current $8-10 \mathrm{nA}$, chamber pressure $10^{-5} \mathrm{~Pa}$. The identification of spectral lines was performed by means of spectral decomposition using the holographic peak deconvolution function. The X-ray photoelectron spectroscopy (XPS) measurements on studied sample surfaces were performed by means of SCIENCE SES 2002 instrument (SCIENTA AB, ScientaOmicron, Uppsala, Sweden) using a monochromatic (Gammadata-Scienta) Al K(alpha), (h $v=1486.6 \mathrm{eV}) \mathrm{X}$-ray source $(18.7 \mathrm{~mA}$, $13.02 \mathrm{kV}$ ). Scan analyses were carried out with an analysis area of $1 \mathrm{~mm} \times 3 \mathrm{~mm}$ and a pass energy of $500 \mathrm{eV}$ with the energy step $0.2 \mathrm{eV}$ and a step time $200 \mathrm{~ms}$. The binding energy of the spectrometer was calibrated by the position of the Fermi level on a clean metallic sample. The power supplies were stable and of high accuracy. The experiments were carried out in an ultrahigh vacuum system (SCIENTA AB, ScientaOmicron, Uppsala, Sweden) with a base pressure of about $6 \times 10^{-8} \mathrm{~Pa}$. The XPS spectra were recorded in normal emission. For the XPS analyses, the CasaXPS 2.3.14 software (Casa Software Ltd., Teignmouth, Devon, UK) (Shirley background type, D.A. Shirley, Lawrence Berkeley National Laboratory, University of California, Berkeley, CA, USA), were used. All the binding energy values presented in this paper were charge corrected to $\mathrm{C} 1 \mathrm{~s}$ at $284.8 \mathrm{eV}$.

\section{RESULTS}

In Figure 1, the SEM images (Fig. 1 a-e) and EDS results (Fig. $1 \mathrm{f}$ ) of titanium samples obtained by PEO treatment at $200 \mathrm{Vpp}$ in electrolyte with concentration of $500 \mathrm{~g} \mathrm{Ca}\left(\mathrm{NO}_{3}\right)_{2} \cdot 4 \mathrm{H}_{2} \mathrm{O}$ per $1 \mathrm{~L}$ of $85 \% \mathrm{H}_{3} \mathrm{PO}_{4}$ during 3 min plasma electrolytic oxidation process, are displayed. Based on the obtained SEM images, the morphology of obtained samples may be described as porous and well developed, where the sharp edges are present. In Figure 1f, the example of EDS spectrum is shown, where the peaks of phosphorus, calcium and titanium, are recorded. Whereas 
there is no doubt that the calcium and phosphorus peaks origin from coatings obtained during the PEO process, the titanium peak may origin from both, obtained coatings and metallic matrix. Therefore, as an independent measure parameter of the mentioned phenomena, metal-tophosphorus ratio (here: calcium-to-phosphorus $\mathrm{Ca} / \mathrm{P}$ ratio), is additionally presented.
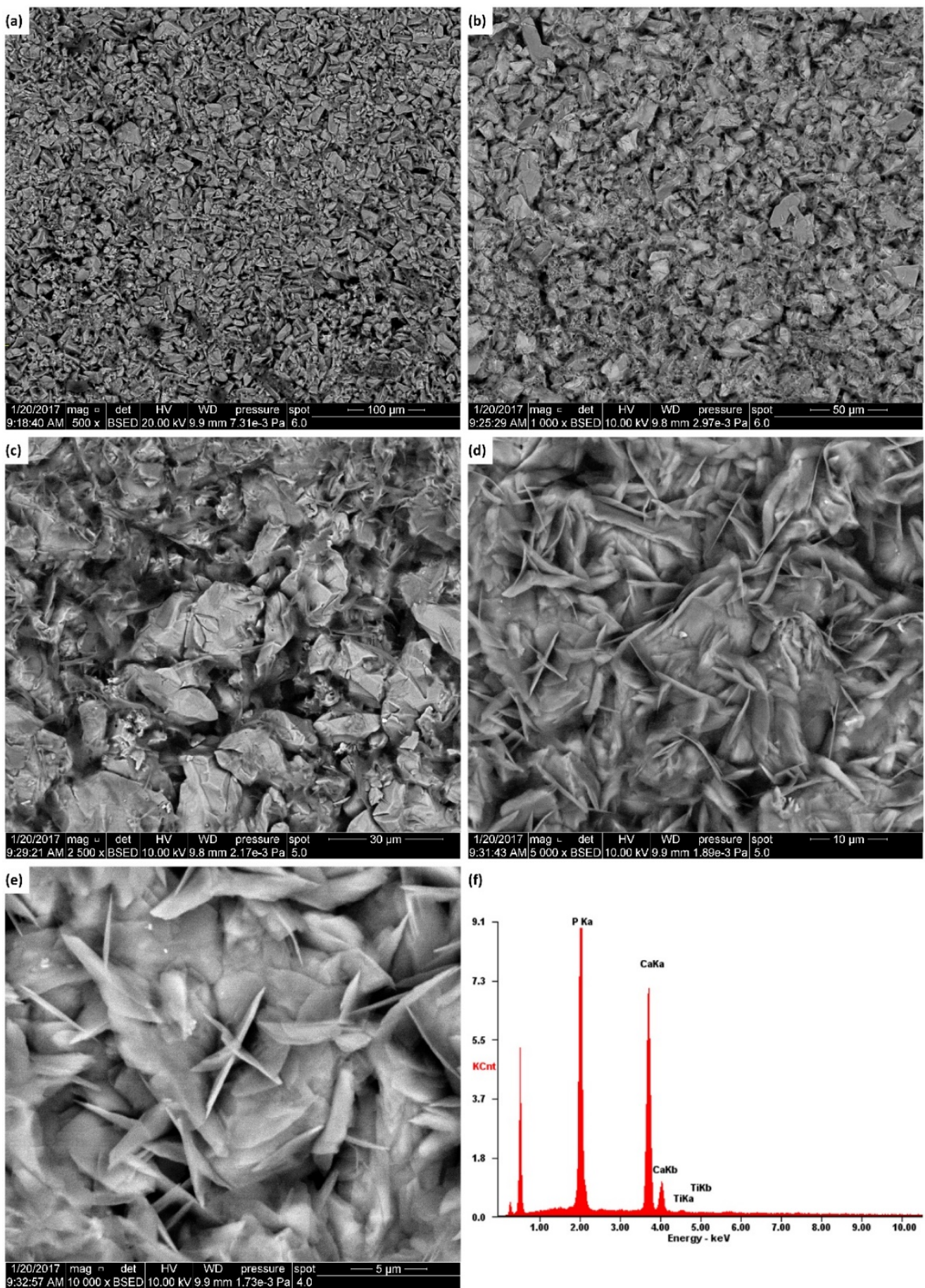

Fig. 1. SEM micrographs with magnifications: 500 times (a), 1000 times (b), 2500 times (c), 5000 times (d), 10000 times (e), and EDS spectrum (f) for samples obtained in AC PEO process in electrolyte consisting of $500 \mathrm{~g}$ $\mathrm{Ca}\left(\mathrm{NO}_{3}\right)_{2} \cdot 4 \mathrm{H}_{2} \mathrm{O}$ in $1 \mathrm{~L}$ of $\mathrm{H}_{3} \mathrm{PO}_{4}$ at $200 \mathrm{~V}_{\mathrm{pp}}$ for 3 min 
The EDS measurements results (Table 1) for samples obtained at $200 \mathrm{Vpp}$ in electrolyte with concentration of $500 \mathrm{~g} \mathrm{Ca}\left(\mathrm{NO}_{3}\right)_{2} \cdot 4 \mathrm{H}_{2} \mathrm{O}$ per $1 \mathrm{~L}$ of $85 \% \mathrm{H}_{3} \mathrm{PO}_{4}$ during 3 min of plasma electrolytic oxidation process as (mean \pm standard deviation) for calcium, phosphorus, and titanium, equaling to $(48.3 \pm 0.5)$ at $\%,(50.9 \pm 0.3)$ at $\%,(0.8 \pm 0.2)$ at $\%$, respectively, and the $\mathrm{Ca} / \mathrm{P}$ ratio equaling to $0.950 \pm 0.015$, were calculated. In our previous paper [19] it has been reported that $\mathrm{Ca} / \mathrm{P}$ ratio $(0.08 \pm 0.01)$ of coatings obtained at $450 \pm 46 \mathrm{~V}$ with pulsation of $300 \mathrm{~Hz}$ was over ten times lower than $\mathrm{Ca} / \mathrm{P}$ value $(0.950 \pm 0.015)$ presented in this paper. It may be explained by differences in coatings' structural composition. In Figure 2, the XPS spectra for the samples obtained at $200 \mathrm{Vpp}$ in electrolyte with concentration of $500 \mathrm{~g} \mathrm{Ca}\left(\mathrm{NO}_{3}\right)_{2} \cdot 4 \mathrm{H}_{2} \mathrm{O}$ per $1 \mathrm{~L}$ of $85 \% \mathrm{H}_{3} \mathrm{PO}_{4}$ during $3 \mathrm{~min}$ of plasma electrolytic oxidation, are presented. The obtained data prove the presence of calcium as $\mathrm{Ca}^{2+}(\mathrm{Ca} 2 \mathrm{~s}, 439.1 \mathrm{eV})$, titanium as $\mathrm{Ti}^{4+}(\mathrm{Ti} 2 \mathrm{p}, 347.5 \mathrm{eV})$, phosphates/polyphosphates as $\mathrm{PO}_{4}{ }^{3-}$ and/or $\mathrm{HPO}_{4}{ }^{2-}$ and/or $\mathrm{H}_{2} \mathrm{PO}_{4}{ }^{-}$, and/or $\mathrm{P}_{2} \mathrm{O}_{7}{ }^{4-}(\mathrm{P} 2 \mathrm{~s}, 191.2$ eV; P2p, $134.0 \mathrm{eV}$; O1s, $531.5 \mathrm{eV}$ ). Based on XPS studies, the top $10 \mathrm{~nm}$ surface layer of the obtained coatings was containing most likely calcium and/or titanium(IV) phosphates, what was also reported in reference [19].

Table 1. EDS results for samples obtained in AC PEO process in electrolyte consisting of $500 \mathrm{~g} \mathrm{Ca}\left(\mathrm{NO}_{3}\right)_{2} \cdot 4 \mathrm{H}_{2} \mathrm{O}$ in $1 \mathrm{~L}$ of $\mathrm{H}_{3} \mathrm{PO}_{4}$ at $200 \mathrm{~V}_{p p}$ for $3 \mathrm{~min}$

\begin{tabular}{cccc}
\hline $\mathrm{Ca}[\mathrm{at} \%]$ & $\mathrm{P}[\mathrm{at} \%]$ & $\mathrm{Ti}[\mathrm{at} \%]$ & $\mathrm{Ca} / \mathrm{P}$ \\
\hline $48.3 \pm 0.5$ & $50.9 \pm 0.3$ & $0.8 \pm 0.2$ & $\begin{array}{c}0.950 \pm \\
0.015\end{array}$ \\
\hline
\end{tabular}

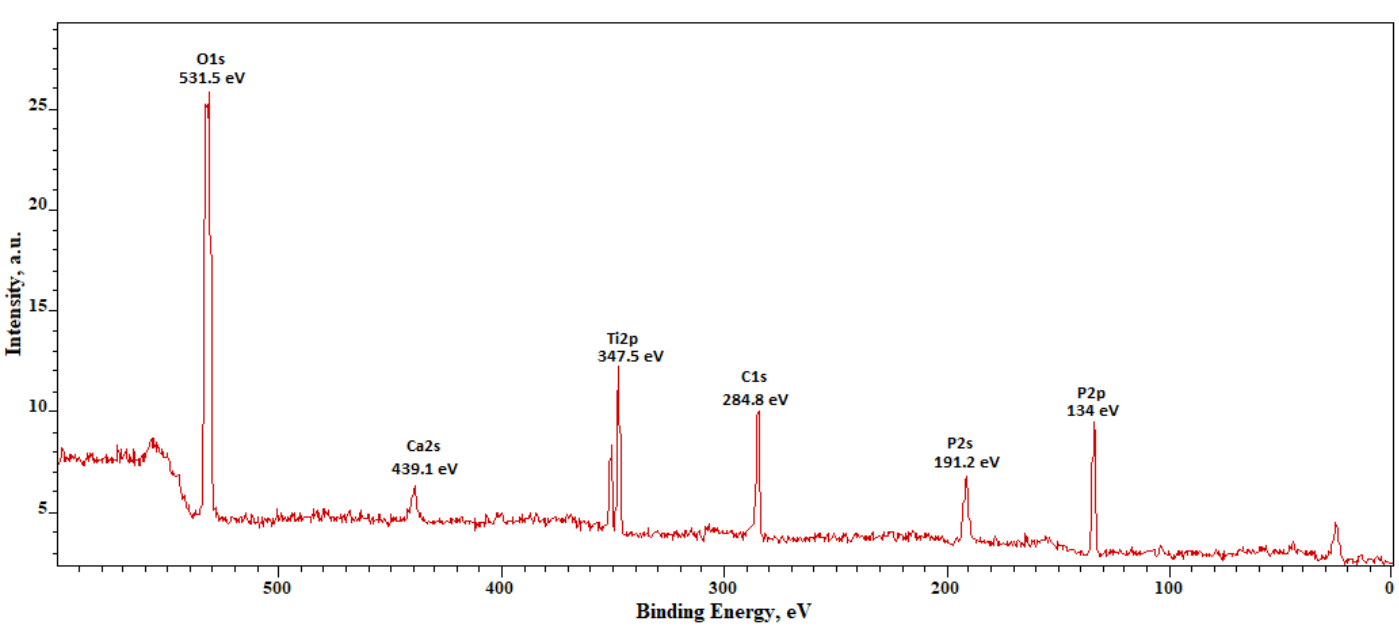

Fig. 2. X-ray Photoelectron Spectroscopy (XPS) spectrum of coating obtained in AC-PEO process in electrolyte containing $500 \mathrm{~g} \mathrm{Ca}(\mathrm{NO} 3) 2 \cdot 4 \mathrm{H} 2 \mathrm{O}$ in $1 \mathrm{~L}$ of $\mathrm{H} 3 \mathrm{PO} 4$ at $200 \mathrm{Vpp}$

The coatings enriched in magnesium, which SEM micrographs are presented in Figure 3 (ae), were obtained at $200 \mathrm{Vpp}$ in electrolyte containing $500 \mathrm{~g} \mathrm{Mg}\left(\mathrm{NO}_{3}\right)_{2} \cdot 6 \mathrm{H}_{2} \mathrm{O}$ per $1 \mathrm{~L}$ of $85 \%$ $\mathrm{H}_{3} \mathrm{PO}_{4}$ during $3 \mathrm{~min}$ of plasma electrolytic oxidation process. Their structures are porous with well-developed surface, but the external pore shapes are different than those ones enriched in calcium, i.e. they have more round-like shapes. The example of EDS spectrum, in which magnesium, phosphorus and titanium are present, is displayed in Figure 3 (f). The EDS results (Table 2) revealing magnesium, phosphorus, and titanium with elemental concentrations equaling to $8.8 \pm 0.5 \mathrm{at} \%, 49.9 \pm 0.6 \mathrm{at} \%$ and $41.3 \pm 1.1 \mathrm{at} \%$, respectively, and $\mathrm{Mg} / \mathrm{P}$ ratio equaling to $0.176 \pm 0.008$, were designated. In our previous paper [20], in which the EDS results of porous 
coatings obtained in the same electrolyte composition, but under DC voltages, i.e. $500 \mathrm{~V}$ and $650 \mathrm{~V}$, the $\mathrm{Mg} / \mathrm{P}$ ratios equaled to $0.16 \pm 0.01$ and $0.17 \pm 0.01$, respectively. Based on those data, a similarity may be noticed between the coatings formed under DC and AC conditions.
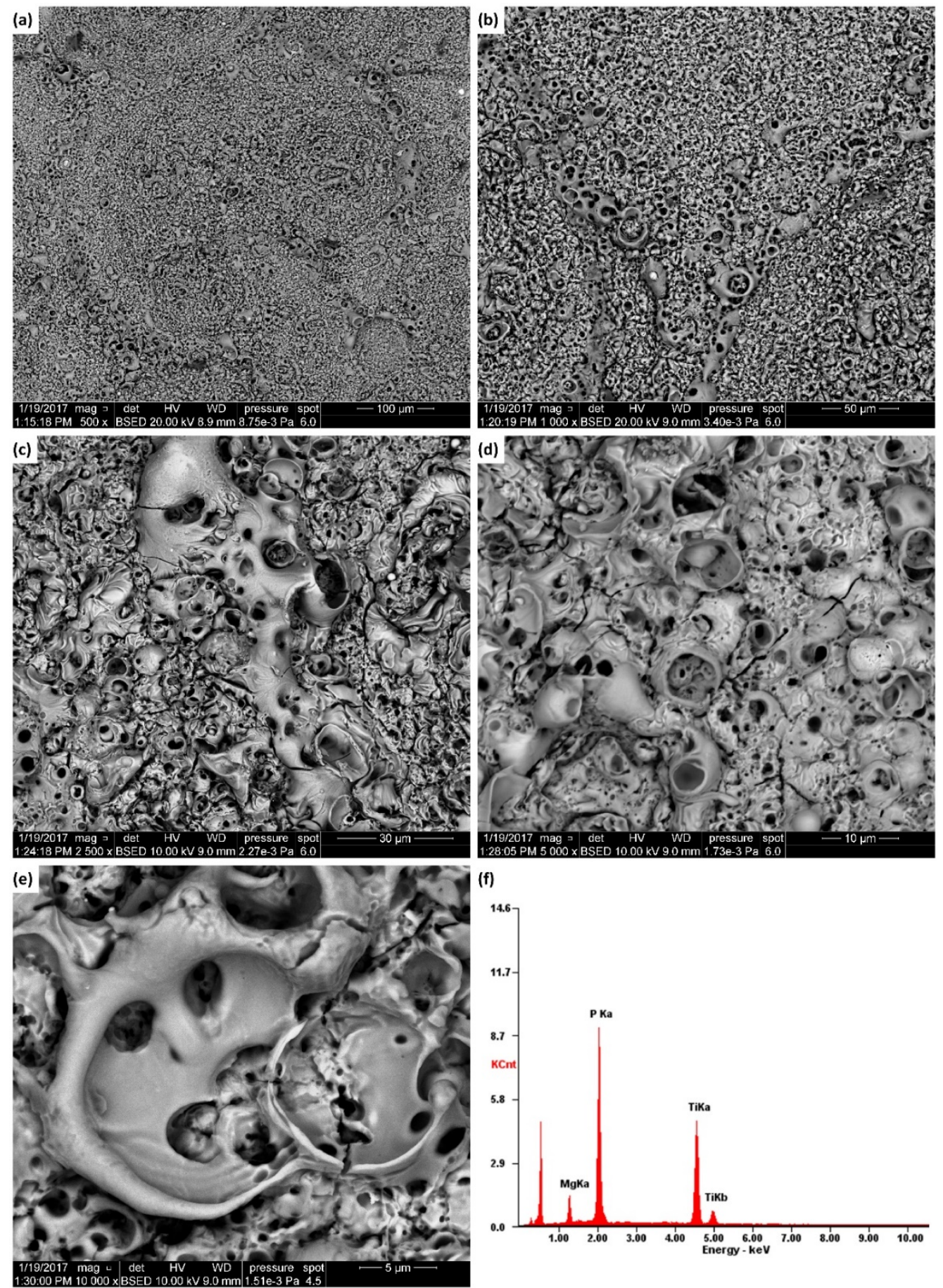

Fig. 3. SEM micrographs with magnifications: 500 times (a), 1000 times (b), 2500 times (c), 5000 times (d), 10000 times (e), and EDS spectrum (f) for samples obtained in AC PEO process in electrolyte consisting of $500 \mathrm{~g}$ $\mathrm{Mg}(\mathrm{NO} 3) 2 \cdot 6 \mathrm{H} 2 \mathrm{O}$ in $1 \mathrm{~L}$ of $\mathrm{H} 3 \mathrm{PO} 4$ at $200 \mathrm{Vpp}$ for 3 min 
The XPS spectrum of coating obtained on titanium sample at $200 \mathrm{Vpp}$ in electrolyte with $500 \mathrm{~g} \mathrm{Mg}\left(\mathrm{NO}_{3}\right)_{2} \cdot 6 \mathrm{H}_{2} \mathrm{O}$ per $1 \mathrm{~L}$ of $85 \% \mathrm{H}_{3} \mathrm{PO}_{4}$ during 3 min of plasma electrolytic oxidation process is presented in Figure 4. Based on these XPS data, it is possible to state that in the topnano-sublayer there are compounds containing mainly magnesium $\mathrm{Mg}^{2+}(\mathrm{Mg} \mathrm{KLL}, 306.7 \mathrm{eV}$; $\mathrm{Mg} 2 \mathrm{~s}, 89.3 \mathrm{eV})$, titanium $\mathrm{Ti}^{4+}(\mathrm{Ti} 2 \mathrm{p}, 459.5 \mathrm{eV})$, and phosphates and/or polyphosphates $\mathrm{PO}_{4}{ }^{3-}$ and/or $\mathrm{HPO}_{4}{ }^{2-}$ and/or $\mathrm{H}_{2} \mathrm{PO}_{4}{ }^{-}, \mathrm{P}_{2} \mathrm{O}_{7}{ }^{4-}(\mathrm{P} 2 \mathrm{~s}, 190.8 \mathrm{eV}$; P2p, $133.7 \mathrm{eV}$; O1s, $531.9 \mathrm{eV})$, what is consistent with the results presented in reference [20].

Table 2. EDS results for samples obtained in AC PEO process in electrolyte consisting of $500 \mathrm{~g} \mathrm{Mg}(\mathrm{NO} 3) 2 \cdot 6 \mathrm{H} 2 \mathrm{O}$ in $1 \mathrm{~L}$ of H3PO4 at $200 \mathrm{Vpp}$ for $3 \mathrm{~min}$

\begin{tabular}{cccc}
\hline $\mathrm{Mg}[\mathrm{at} \%]$ & $\mathrm{P}[\mathrm{at} \%]$ & $\mathrm{Ti}[\mathrm{at} \%]$ & $\mathrm{Mg} / \mathrm{P}$ \\
\hline $8.8 \pm 0.5$ & $49.9 \pm 0.6$ & $41.3 \pm 1.1$ & $\begin{array}{c}0.176 \pm \\
0.008\end{array}$ \\
\hline
\end{tabular}

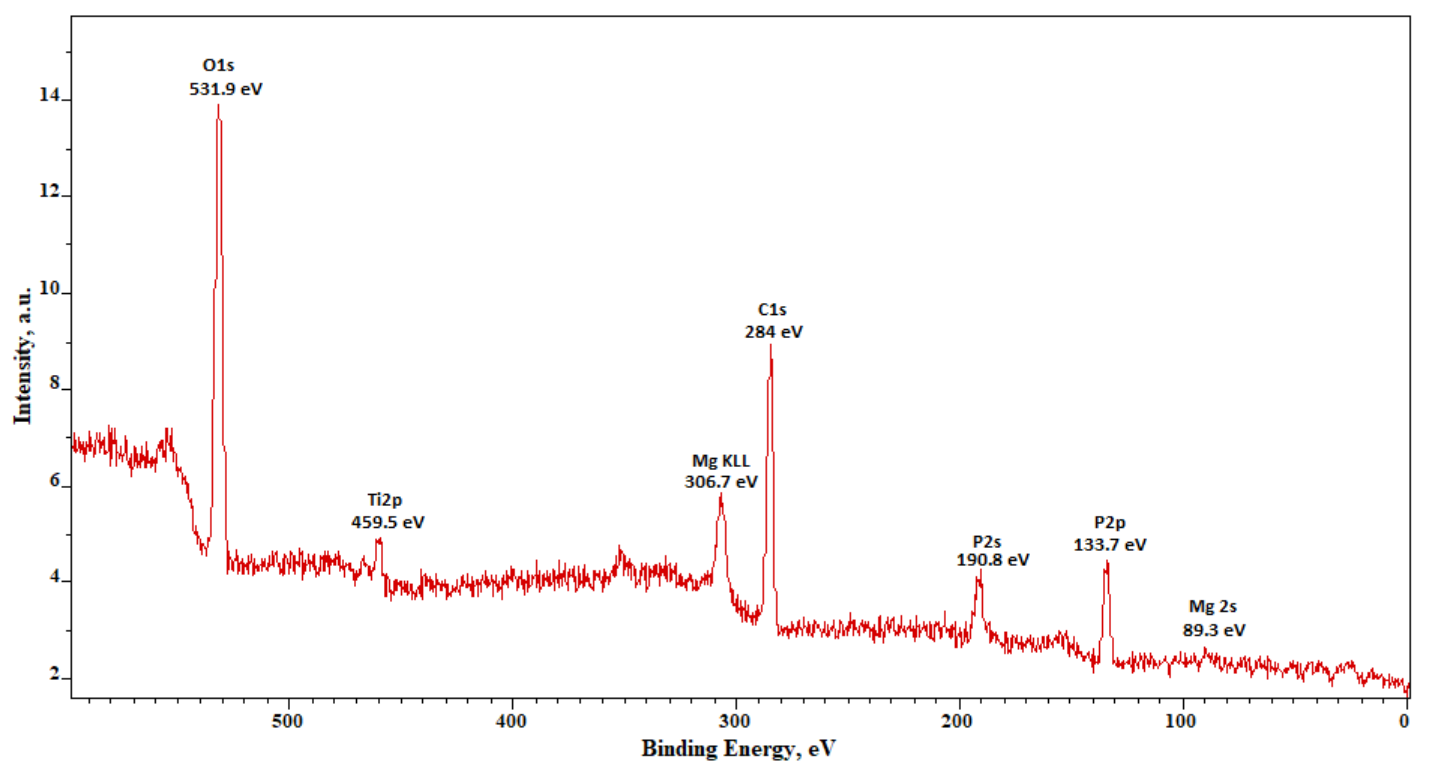

Fig. 4. X-ray Photoelectron Spectroscopy (XPS) spectra of samples obtained in AC PEO process in electrolyte consisting of $500 \mathrm{~g} \mathrm{Mg}(\mathrm{NO} 3) 2 \cdot 6 \mathrm{H} 2 \mathrm{O}$ in $1 \mathrm{~L}$ of $\mathrm{H} 3 \mathrm{PO} 4$ at $200 \mathrm{Vpp}$ for $3 \mathrm{~min}$

In Figure 5 (a-f), the SEM images of PEO coatings obtained at $200 \mathrm{Vpp}$ in electrolyte with concentration of $500 \mathrm{~g} \mathrm{Zn}\left(\mathrm{NO}_{3}\right)_{2} \cdot 6 \mathrm{H}_{2} \mathrm{O}$ per $1 \mathrm{~L}$ of $85 \% \mathrm{H}_{3} \mathrm{PO}_{4}$ during 3 min of plasma electrolytic oxidation process, are presented. Morphologies of these samples are similar to those ones obtained at $200 \mathrm{Vpp}$ in electrolyte with concentration of $500 \mathrm{~g} \mathrm{Zn}\left(\mathrm{NO}_{3}\right)_{2} \cdot 6 \mathrm{H}_{2} \mathrm{O}$ per $1 \mathrm{~L}$ of $85 \% \mathrm{H}_{3} \mathrm{PO}_{4}$ during 3 min of $\mathrm{PEO}$ process. 

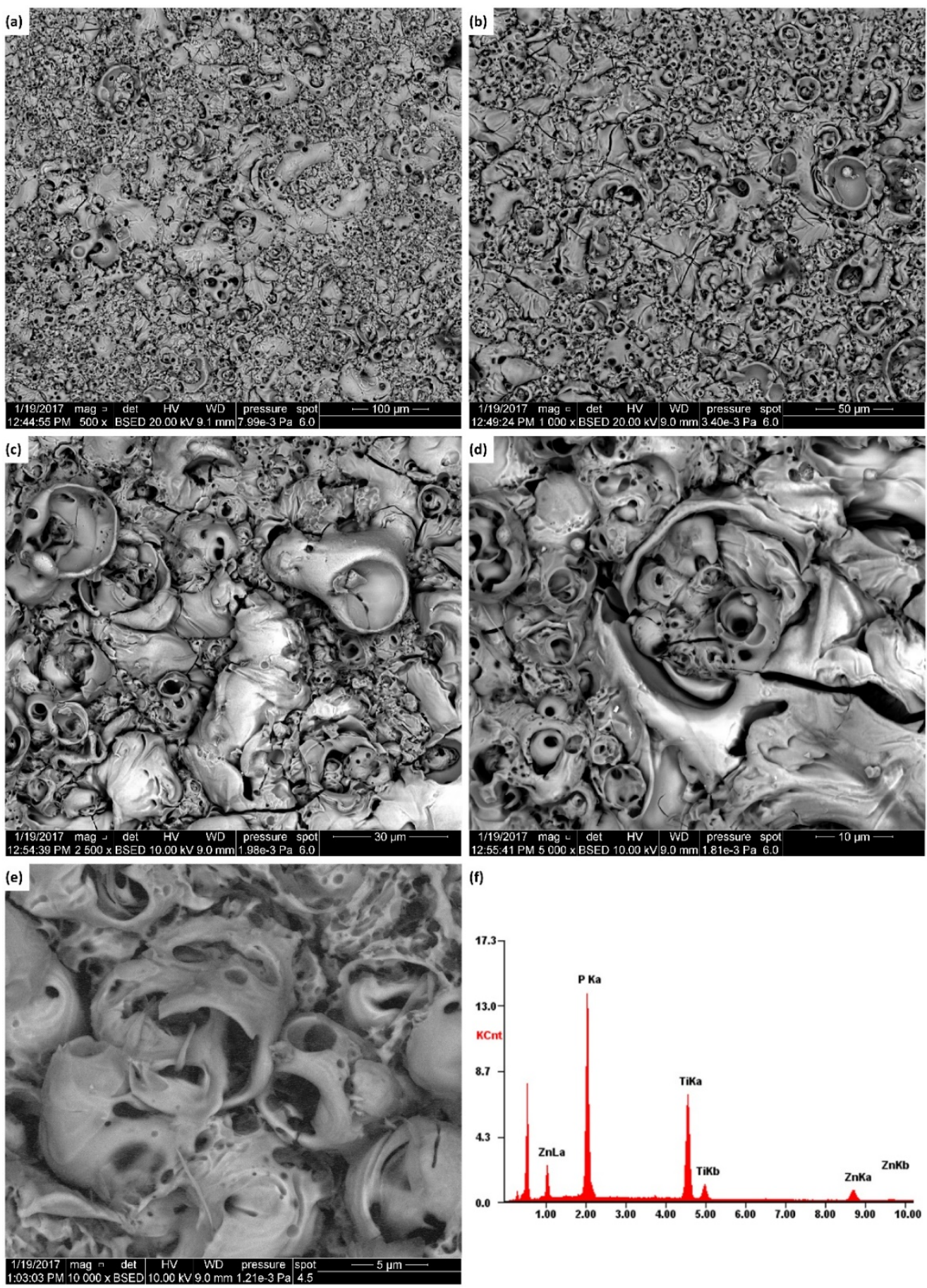

\section{(f)}

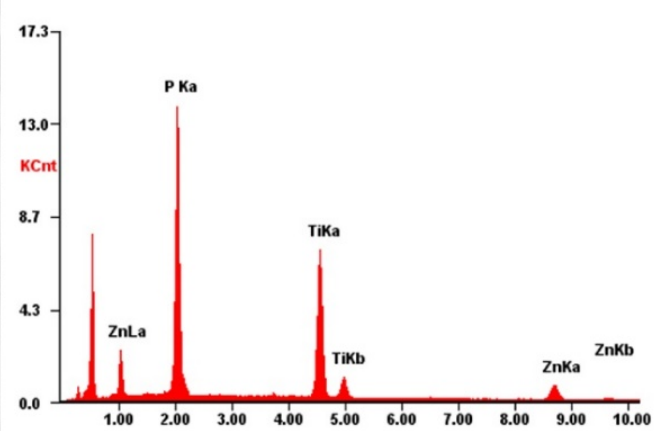

Fig. 5. SEM micrographs with magnifications: 500 times (a), 1000 times (b), 2500 times (c), 5000 times (d), 10000 times (e) and EDS spectrum (f) for samples obtained in AC PEO process in electrolyte consisting of $500 \mathrm{~g}$ $\mathrm{Zn}(\mathrm{NO} 3) 2 \cdot 6 \mathrm{H} 2 \mathrm{O}$ in $1 \mathrm{~L}$ of $\mathrm{H} 3 \mathrm{PO} 4$ at $200 \mathrm{Vpp}$ for 3 min

Based on EDS results of zinc enriched coatings (Table 3), the presence of zinc, phosphorus and titanium elements, was confirmed. The atomic concentrations of zinc, phosphorus and titanium in these coatings are equaling to $11.7 \pm 0.7,50.6 \pm 0.3,37.7 \pm 0.7$, respectively. The 
$\mathrm{Zn} / \mathrm{P}$ ratio equals to $0.231 \pm 0.014$ and it is close to the value from the reference [20], i.e. 0.12 $0.20(500 \mathrm{~V}-650 \mathrm{~V})$.

The XPS spectra of sample obtained at $200 \mathrm{Vpp}$ in electrolyte with concentration of $500 \mathrm{~g}$ $\mathrm{Mg}\left(\mathrm{NO}_{3}\right)_{2} \cdot 6 \mathrm{H}_{2} \mathrm{O}$ per $1 \mathrm{~L}$ of $85 \%$ concentrated $\mathrm{H}_{3} \mathrm{PO}_{4}$ during 3 min of plasma electrolytic oxidation process are presented in Figure 6. Based on these results, it may be stated that external, top part of coatings consists mainly of zinc $\mathrm{Zn}^{2+}(\mathrm{Zn} 2 \mathrm{~s}, 1021.3 \mathrm{eV})$, titanium $\mathrm{Ti}^{4+}$ (Ti2p, 459.6 $\mathrm{eV}$ ), and phosphates $\mathrm{PO}_{4}{ }^{3-}$ and/or $\mathrm{HPO}_{4}{ }^{2-}$ and/or $\mathrm{H}_{2} \mathrm{PO}_{4}{ }^{-}$, and/or $\mathrm{P}_{2} \mathrm{O}_{7}{ }^{4-}$ (P2s, $191.0 \mathrm{eV} ; \mathrm{P} 2 \mathrm{p}$, $133.6 \mathrm{eV}$; O1s, $531.0 \mathrm{eV}$; O KLL $976.2 \mathrm{eV}$ ).

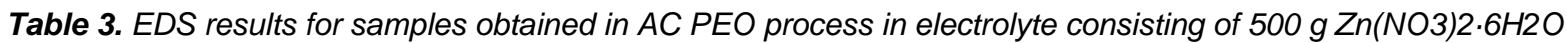
in $1 \mathrm{~L}$ of $\mathrm{H} 3 \mathrm{PO} 4$ at $200 \mathrm{Vpp}$

\begin{tabular}{cccc}
\hline $\mathrm{Zn}[\mathrm{at} \%]$ & $\mathrm{P}[\mathrm{at} \%]$ & $\mathrm{Ti}[\mathrm{at} \%]$ & $\mathrm{Zn} / \mathrm{P}$ \\
\hline $11.7 \pm 0.7$ & $50.6 \pm 0.3$ & $37.7 \pm 0.7$ & $\begin{array}{c}0.231 \pm \\
0.014\end{array}$ \\
\hline
\end{tabular}

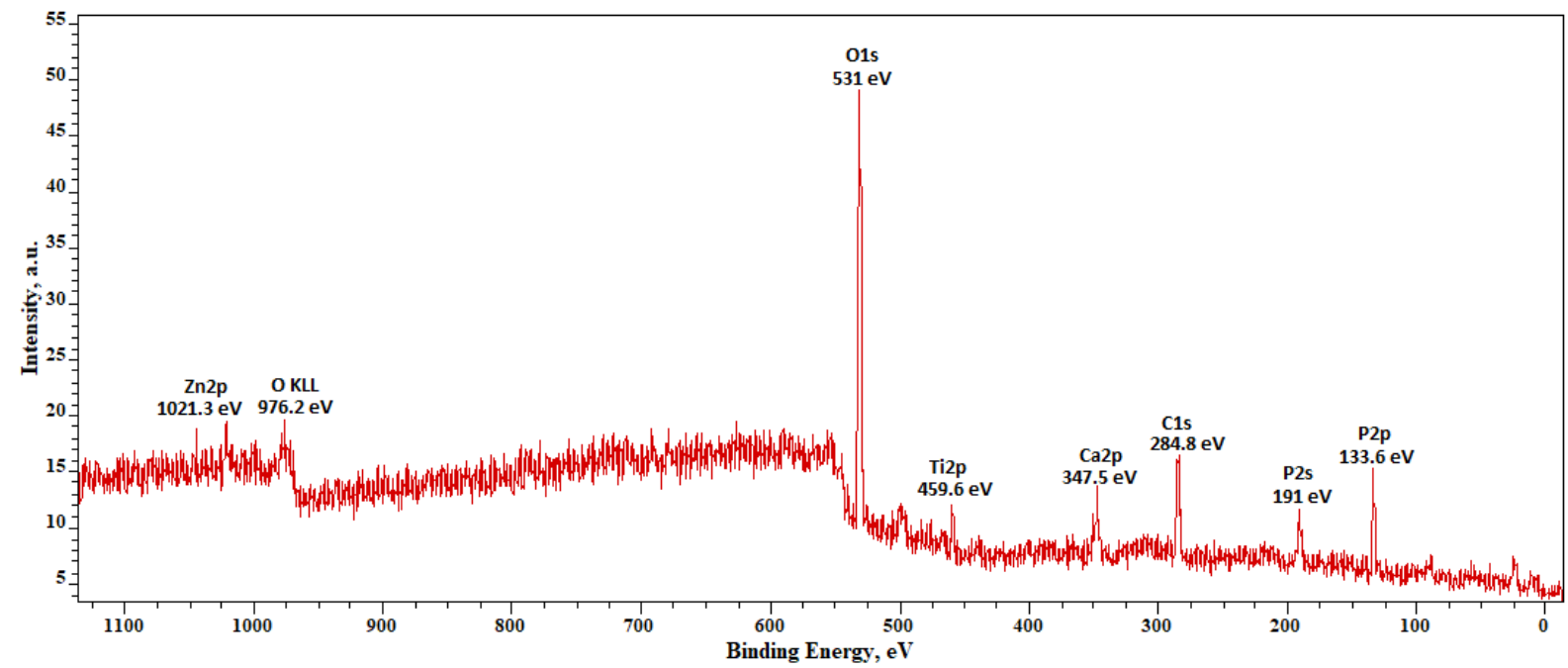

Fig. 6. X-ray Photoelectron Spectroscopy (XPS) spectra of samples obtained in AC PEO process in electrolyte consisting of $500 \mathrm{~g} \mathrm{Zn(NO3)2.6H2O} \mathrm{in} 1 \mathrm{~L}$ of H3PO4 at $200 \mathrm{Vpp}$ for $3 \mathrm{~min}$

To summarize, the EDS results of calcium, magnesium, zinc, phosphorus, and titanium atomic concentrations (a) and metal-to-phosphorus ratios (b) in Figure 7, are presented. Concentrations of calcium in the obtained coatings is significantly higher (more than four times) than concentrations of magnesium and zinc at the same voltage conditions, what is confirmed by differences between $\mathrm{Ca} / \mathrm{P}, \mathrm{Mg} / \mathrm{P}$, and $\mathrm{Zn} / \mathrm{P}$ ratios. 
(a)

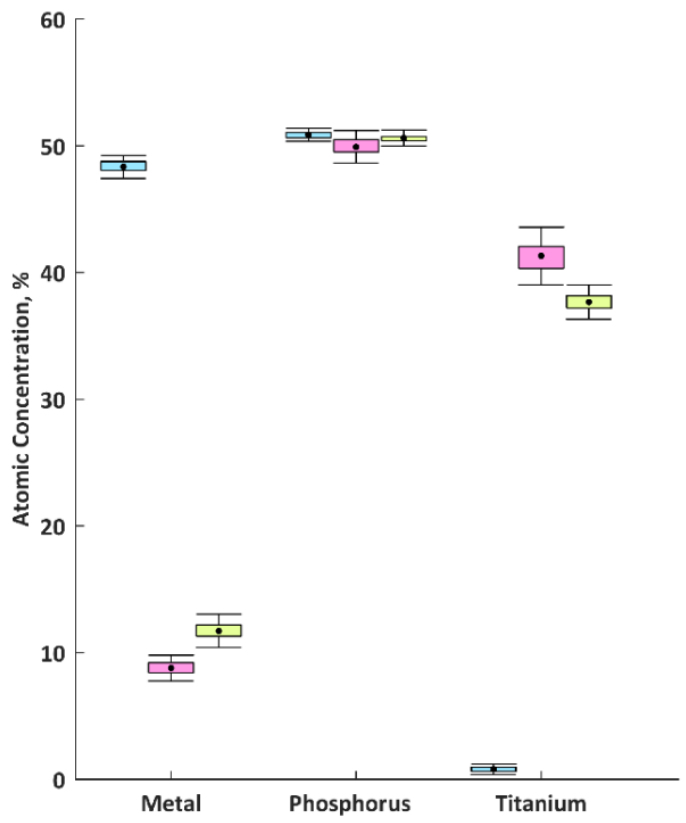

(b)

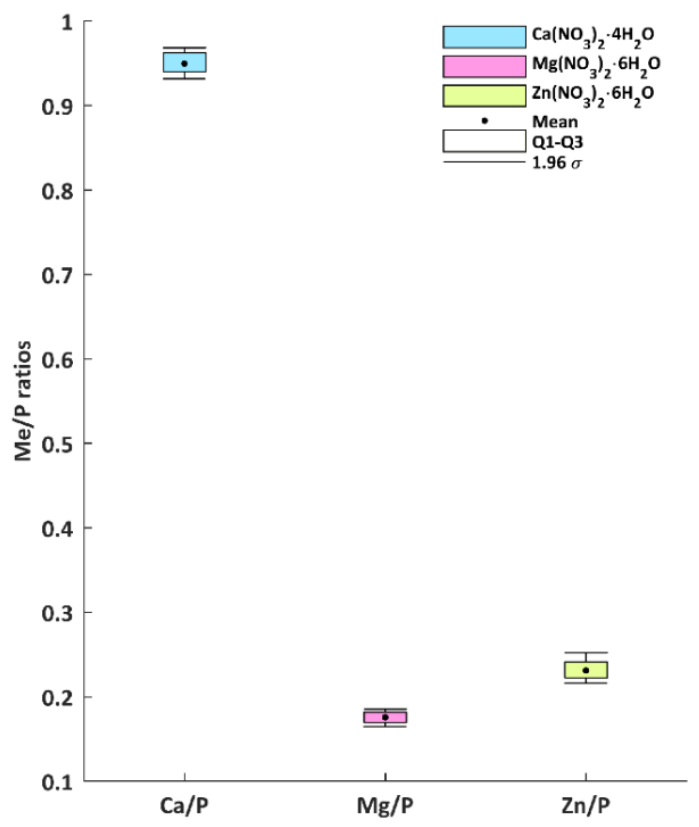

Fig. 7. EDS results for samples obtained in three electrolytes: $\mathrm{Ca}(\mathrm{NO} 3) 2 \cdot 4 \mathrm{H} 2 \mathrm{O}$ in $1 \mathrm{~L}$ of $\mathrm{H} 3 \mathrm{PO} 4 ; 500 \mathrm{~g}$

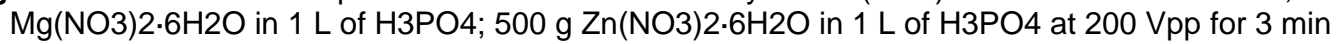

CONCLUSIONS

During the PEO processes performed for 3 minutes at the voltage of $200 \mathrm{~V}_{\mathrm{pp}}$ with the use of $50 \mathrm{~Hz}$ AC power transformer it was possible to obtain porous coatings enriched in calcium, or magnesium, or zinc with visible differences in morphology. Based on EDS data analysis it is possible to state that the ratios are as follows: $\mathrm{Ca} / \mathrm{P}>>\mathrm{Zn} / \mathrm{P}>\mathrm{Mg} / \mathrm{P}$, that cannot be explained by differences in molar masses of salts used to prepare electrolytes, and most likely the mechanism of plasma electrolytic oxidation process, in these particular AC conditions, may play a main role. In all three obtained coatings, i.e. enriched with calcium, or magnesium, or zinc, beside the mentioned elements specific for type of the electrolyte, titanium as four-valent cations and phosphorus in the chemical form of phosphates/polyphosphates in the top $10 \mathrm{~nm}$ layer are present. This finding is in common with the previous publications [18-20]. The presence of phosphates of calcium, or magnesium, or zinc in the porous PEO coatings stands a very good forecast for application in the field of biomedicine.

\section{ACKNOWLEDGMENTS}

Acknowledgments: This work was supported by a subsidizing by Grant OPUS 11 of National Science Centre, Poland, with registration number 2016/21/B/ST8/01952, titled "Development of models of new porous coatings obtained on titanium by Plasma Electrolytic Oxidation in electrolytes containing phosphoric acid with addition of calcium, magnesium, copper and zinc nitrates". 


\section{REFERENCES}

1. Rokosz K., Hryniewicz T., Simon F., Rzadkiewicz S.: Comparative XPS analysis of passive layers composition formed on AISI 304 L SS after standard and high-current density electropolishing. Surf. Interface Analysis 47 (2015), 87-92.

2. Rokosz K., Lahtinen J., Hryniewicz T., Rzadkiewicz S.: XPS depth profiling analysis of passive surface layers formed on austenitic AISI 304L and AISI 316L SS after high-current-density electropolishing. Surface and Coatings Technology 276 (2015), 516-520.

3. Rokosz K., Hryniewicz T., Raaen S.: Cr/Fe ratio by XPS spectra of magnetoelectropolished AISI 316L SS fitted by Gaussian-Lorentzian shape lines. Tehnicki Vjesnik-Technical Gazette 21(3) (2014), 533-538.

4. Hryniewicz T., Rokosz K., Rokicki R., Prima F.: Nanoindentation and XPS Studies of Titanium TNZ Alloy after Electrochemical Polishing in a Magnetic Field. Materials. 8 (2015), 205-215.

5. Aliasghari S., Plasma Electrolytic Oxidation of Titanium, PhD Thesis of Faculty of Engineering and Physical Sciences, The University of Manchester School of Materials, 2014, 223 pages.

6. Gowtham S., Arunnellaiappan T., Rameshbabu N.: An investigation on pulsed DC plasma electrolytic oxidation of $\mathrm{cp}$-Ti and its corrosion behaviour in simulated body fluid. Surf. Coat. Technol. 301 (2016), 63-73.

7. Wang Y., Jiang B., Lei T., Guo L.: Dependence of growth features of microarc oxidation coatings of titanium alloy on control modes of alternate pulse. Materials Letters 58 (2004), 1907-1911.

8. Simka W., Sadowski A., Warczak M., Iwaniak A., Dercz G., Michalska J., Maciej A.: Modification of titanium oxide layer by calcium and phosphorus. Electrochimica Acta 56(24) (2011), 8962-8968.

9. Krząkala A., Mlynski J., Dercz G., Michalska J., Maciej A., Nieużyla L., Simka W.: Modification of Ti-6Al-4V alloy surface by EPD-PEO process in $\mathrm{ZrSiO} 4$ suspension. Archives of Metallurgy and Materials 59(1) (2014), 199-204.

10. Rokosz K., Hryniewicz T., Raaen S.: Development of Plasma Electrolytic Oxidation for improved Ti6Al4V biomaterial surface properties. The International Journal of Advanced Manufacturing Technology. 85 (2016), 2425-2437.

11. Kazek-Kęsik A., Kuna K., Dec W., Widziołek M., Tylko G., Osyczka A.M., Simka W.: In vitrobioactivity investigations of Ti-15Mo alloy after electrochemical surface modification. Journal of Biomedical Materials Research Part B: Applied Biomaterials. 104B (2015), 903-913.

12. Rokosz K., Hryniewicz T., Raaen S.: SEM, EDS and XPS analysis of nanostructured coating obtained on NiTi biomaterial alloy by Plasma Electrolytic Oxidation (PEO). Tehnički VjesnikTechnical Gazette. 24(1) (2017), 193-198.

13. Simka W., Nawrat G., Chlode J., Maciej A., Winiarski A., Szade J., Radwanski K., Gazdowicz J.: Electropolishing and anodic passivation of Ti6Al7Nb alloy. Przemysł Chemiczny. 90(1) (2011), 8490.

14. Rokosz K., Hryniewicz T., Raaen S., Chapon P.: Investigation of porous coatings obtained on Ti-Nb$\mathrm{Zr}-\mathrm{Sn}$ alloy biomaterial by Plasma Electrolytic Oxidation: Characterisation and Modelling. The International Journal of Advanced Manufacturing Technology 87(9) (2016) 3497-3512.

15. Han Y., Hong S.H., Xu K.W.: Structure and in vitro bioactivity of titania-based films by micro-arc oxidation. Surface and Coatings Technology 168 (2003) 249-258.

16. El Achhaba M., Schierbaum K.: Structure and hydrogen sensing properties of plasma 
electrochemically oxidized titanium foils. Procedia Engineering 47 (2012), 566-569; doi:10.1016/j.proeng.2012.09.210.

17. Peng B.Y., Nie X., Chen Y.: Effects of Surface Coating Preparation and Sliding Modes on Titanium Oxide Coated Titanium Alloy for Aerospace Applications. Int. J. Aerospace. Eng. 2014 (2014), 640364, 1-10; doi:10.1155/2014/640364.

18. Rokosz K., Hryniewicz T., Dalibor M., Raaen S., Valiček J., Dudek Ł., Harničarova M.: SEM, EDS and XPS Analysis of the Coatings Obtained on Titanium after Plasma Electrolytic Oxidation in Electrolytes Containing Copper Nitrate. Materials 9(5) (2016), 1-12.

19. Rokosz K., Hryniewicz T., Gaiaschi S., Chapon P., Raaen S., Pietrzak K., Malorny W.: Characterisation of Calcium- and Phosphorus-Enriched Porous Coatings on CP Titanium Grade 2 Fabricated by Plasma Electrolytic Oxidation. Metals 7 (2017), 354; doi:10.3390/met7090354.

20. Rokosz K., Hryniewicz T., Gaiaschi S., Chapon P., Raaen S., Pietrzak K., Malorny W., Salvador Fernandes J.: Characterization of Porous Phosphate Coatings Enriched with Magnesium or Zinc on CP Titanium Grade 2 under DC Plasma Electrolytic Oxidation. Metals 8 (2018), 112; doi:10.3390/met8020112. 